\title{
FAKTOR-FAKTOR YANG MEMPENGARUHI BELANJA DAERAH SERTA DAMPAKNYA TERHADAP PRODUK DOMESTIK REGIONAL BRUTO KABUPATEN BERAU
}

\author{
Elita Herlina \\ Fakultas Ekonomi Universitas Mulawarman \\ E-mail: elitaherlina@gmail.com
}

\begin{abstract}
The study was intended to: 1) analyze the direct influence of Regional Income (PAD), General Allocation Fund (DAU), and the population toward Regional Expenditure. 2) Investigate the direct effects of Regional Income (PAD), General Allocation Fund (DAU) and the population to the Gross Domestic Regional Product (GDP). 3) Define the straight impact of regional expenditure to GDP in Berau. 4) Explain the indirect effects of Regional Income (PAD), the General Allocation Fund (DAU), and the population to GDP through the regional expenditure. 5) Describe the dominant effects of Regional Income (PAD), the general allocation fund (DAU) and the population to regional expenditure and GDP. The data used in this study were secondary and time series data. The result showed that Regional Income (PAD), General Allocation Fund (DAU), and total population have direct strong influence on regional expenditure and GDP. On the other hand, these factors have no significant impact to GDP through regional expenditure.
\end{abstract}

Keywords: Regional Income (PAD), the General Allocation Fund (DAU), Population, Regional Expenditure, Gross Domestic Regional Product (PDRB).

\begin{abstract}
Abstrak
Tujuan penelitian ini adalah: 1) Menganalisis pengaruh pendapatan asli daerah (PAD), dana alokasi umum (DAU) dan jumlah penduduk secara langsung terhadap belanja daerah. 2) Menganalisis pengaruh pendapatan asli daerah (PAD), dana alokasi umum (DAU) dan jumlah penduduk secara langsung terhadap PDRB. 3) Menganalisis pengaruh belanja daerah secara langsung terhadap PDRB di Kabupaten Berau. 4) Menganalisis pengaruh pendapatan asli daerah (PAD), dana alokasi umum (DAU) dan jumlah penduduk secara tidak langsung terhadap PDRB melalui belanja daerah. 5) Menganalisis pengaruh pendapatan asli daerah (PAD), dana alokasi umum (DAU) dan jumlah penduduk secara dominan terhadap belanja daerah dan PDRB. Data yang digunakan dalam penelitian ini data skunder dan time serries Hasil analisis menunjukkan bahwa terdapat pengaruh langsung antara pendapatan asli daerah (PAD), dana alokasi umum (DAU), jumlah penduduk terhadap belanja daerah dan PDRB. Terdapat pengaruh tidak langsung antara pendapatan asli daerah (PAD), dana alokasi umum (DAU), jumlah penduduk terhadap PDRB melalui belanja daerah.
\end{abstract}

Kata Kunci: Pendapatan Asli Daerah (PAD), Dana Alokasi Umum (DAU), Jumlah Penduduk, Belanja Daerah, PDRB. 
Pertumbuhan ekonomi merupakan syarat yang diperlukan dalam melaksanakan pembangunan ekonomi. Pertumbuhan juga merupakan ukuran utama keberhasilan pembangunan. Pertumbuhan ekonomi mengukur prestasi dari perkembangan suatu perekonomian dari suatu periode ke periode berikutnya. Kemampuan suatu negara untuk menghasilkan barang dan jasa akan meningkat yang disebabkan oleh faktor-faktor produksi yang selalu mengalami pertambahan dalam jumlah dan kualitasnya. Menurut Sukirno (2004) dalam analisis makro, tingkat pertumbuhan ekonomi yang dicapai oleh suatu negara diukur dari perkembangan pendapatan nasional riil yang dicapai suatu Negara atau daerah.

Pembangunan daerah merupakan bagian integral daripembangunan nasional yang dilaksanakan dalam meningkatkan kesejahteraan masyarakat. Kemajuan pertumbuhan ekonomi yang berkesinambungan di setiap daerah menjadi perhatian pemerintah karena pada dasarnya pertumbuhan ekonomi nasional merupakan agregasi pertumbuhan ekonomi daerah. Pertumbuhan ekonomi antar daerah di Indonesia sangat beragam. Keragaman tersebut menjadi salah satu faktor yang memunculkan konsepsi daerah maju-tertinggal.

Pemberlakuan UU Nomor 22 tahun 1999 tentang Pemerintah Daerah dan UU Nomor 25 tahun 1999 tentang Perimbangan Keuangan antara Pemerintah Pusat dan Pemerintah Daerah mulai 1 Januari 2001, yang kemudian diperbarui dengan UU No. 32/2004 dan UU No. 33/2004, memberikan kewenangan yang lebih besar kepada pemerintah daerah dalam mengelola pemerintahan dan keuangan daerah. Otonomi daerah mempunyai tujuan dalam rangka mencapai kemandirian daerah dalam pe- laksanaan pemerintahan dan pembangunan. Hal tersebut dimaksudkan bahwa daerah lebih mengerti kondisi daerahnya sehingga pembangunan daerah akan dapat difokuskan pada prioritas kebutuhan dan potensi yang dimiliki daerah masing-masing.

Untuk meningkatkan pertumbuhan ekonomi, salah satu cara yang dapat dilakukan adalah dengan meningkatkan belanja pemerintah daerah. Sodik (2007) mengemukakan bahwa belanja pemerintah daerah (baik belanja rutin maupun pembangunan) berpengaruh signifikan terhadap pertumbuhan ekonomi. Belanja pemerintah daerah merupakan bentuk rangsangan atau stimulus yang dilakukan untuk memacu perkembangan perekonomian daerah.

Pertumbuhan ekonomi di Kabupaten Berau sejalan dengan perkembangan ekonomi nasional yaitu mengalami pertumbuhan yang sangat signifikan, bahkan di Kabupaten Berau sendiri mengalami percepatan pertumbuhan ekonomi cukup tinggi. Pertumbuhan ekonomi didorong oleh membaiknya aktivitas Pertambangan dan pergerakan positif sektor Perdagangan serta sektor-sektor lainnya. besaran atau nilai Produk Domestik Regional Bruto (Gross Regional Domestic Product) Kabupaten Berau atas dasar harga berlaku tahun 2011 yaitu sebesar 9.607,4268 milyar rupiah, sedangkan pada tahun 2010 sebesar 8.079,2285 juta rupiah berarti ada kenaikan atau peningkatan sebesar 1.528, 1983 milyar rupiah, hal ini disebabkan oleh naiknya produksi barang dan jasa dan didorong oleh peningkatan harga global komoditas ekspor.

Produk Domestik Regional Bruto (Gross Regional Domestic Product) atas dasar harga konstan tahun 2000, pada tahun 2011 sebesar 4.967,3144 milyar rupiah sedangkan pada tahun 2010 sebesar 
Faktor-faktor yang Mempengaruhi Belanja Daerah Serta Dampaknya.... (Elita Herlina)

4.602,1688 yang berarti mengalami kenaikan atau peningkatan sebesar 365,1457 milyar rupiah atau mengalami pertumbuhan sebesar 7,93 persen. Pertumbuhan yang positif menunjukkan kenaikan produksi barang dan jasa di daerah tersebut. Nilai Nominal PDRB merupakan besaran nilai tambah dari masing-masing sektor Ekonomi (PDRB atas dasar harga berlaku) dan digunakan untuk mengetahui potensi ekonomi suatu daerah dalam mengelolah sumber Daya Alam (SDA) dan Sumber daya Manusia (SDM). Sedangkan laju pertumbuhan ekonomi salah satu indikator tingkat keberhasilan pembangunan suatu daerah dalam periode tertentu dan untuk mengukur kinerja ekonomi suatu daerah dalam periode tertentu.

Kontribusi belanja pemerintah daerah terhadap PDRB berkisar antara 20-25 persen, berbeda dengan nasional yang hanya sembilan persen terhadap PDB. Campur tangan pemerintah daerah yang masih besar sesuai dengan tahap perkembangan pengeluaran pemerintah yang masih berada di tahap awal perkembangan. Pengelolaan keuangan pemerintah daerah tidak saja mencerminkan arah dan pencapaian kebijakan fiskal dalam mendorong pembangunan di daerah secara umum, tetapi juga menggambarkan sejauh mana tugas dan kewajiban yang diembankan pada pemerintah daerah dalam konteks desentralisasi fiskal itu dilaksanakan. Hasil pertumbuhan ekonomi diarahkan agar dapat dinikmati masyarakat sampai di lapisan paling bawah, baik dengan sendirinya maupun dengan campur tangan pemerintah.

Struktur ekonomi daerah diukur dari peran masing-masing sektor atau lapangan usaha terhadap total PDRB. Semakin besar nilai tambah yang tercipta disuatu sektor eko- nomi akan membuat peran sektor tersebut semakin penting. Struktur ekonomi suatu daerah menjadi faktor penentu apakah daerah tersebut didominasi oleh sektor primer, sekunder atau tersier. Sektor primer adalah sektor yang masih banyak mengandalkan peran sumber daya alam dalam proses produksi yaitu sektor pertanian dan sektor pertambangan dan penggalian.

Sektor sekunder adalah sektor yang tidak terlalu mengandalkan peran sumber daya alam, akan tetapi lebih banyak mengandalkan kemajuan teknologi dan peran sumber daya manusia yaitu sektor industri pengolahan, listrik dan air serta konstruksi. Sedangkan sektor tersier adalah sektor yang bisa dikatakan tidak mengandalkan sumber daya alam lagi yaitu sektor perdagangan, pengangkutan dan telekomunikasi, bank dan lembaga keuangan lain dan sektor jasa-jasa.

Struktur ekonomi Kabupaten Berau yang memberikan kontribusi yang terbesar adalah tiga sektor masing-masing, pertama Sektor Pertambangan dan penggalian, sektor ini mengandalkan sektor Sumber Daya Alam yaitu sebesar 5.488,01 milyar rupiah atau sebesar 57,12 persen, kedua sektor Pertanian yaiu sebesar 1.316,36 milyar rupiah atau sebesar 13,70 persen dan ketiga yaitu sektor Perdagangan, Hotel dan Restoran sebesar 1.028,76 milyar rupiah atau sebesar 10,71 persen. Nilai tambah atau prosentase untuk masing-masing sektor secara keseluruhan dapat dilihat pada tabel 1.

Pendapatan asli daerah merupakan salah satu sumber utama pendapatan yang diperoleh daerah yang dipungut berdasarkan peraturan daerah sesuai dengan peraturan perundang-undangan. Dengan adanya desentralisasi fiskal, daerah mempunyai kewenangan yang lebih besar untuk mengoptimalkan pendapatan asli daerahnya se- 
Ekonomika-Bisnis Vol. 4 No.1 Bulan Januari Tahun 2013. Hal 25-44

Tabel 1. Struktur Ekonomi Kabupaten Berau

\begin{tabular}{lllllll}
\hline No & Lapangan Usaha & 2007 & 2008 & 2009 & 2010 & 2011 \\
\hline & & & & & & \\
1 & Pertanian & 15,12 & 14,43 & 13,79 & 12,89 & 13,70 \\
2 & Pertambangan \& pengglian & 50,69 & 51,99 & 53,10 & 55,70 & 57,12 \\
3 & Industri pengolahan & 11,67 & 10,93 & 10,10 & 9,22 & 8,08 \\
4 & Listrik dan air & 0,16 & 0,15 & 0,15 & 0,14 & 0,15 \\
5 & Bangunan & 0,95 & 0,97 & 1,03 & 1,02 & 1,07 \\
6 & Perdagangan hotel \& restrn & 10,21 & 10,61 & 11,23 & 11,03 & 10,71 \\
7 & Pengangkutan \& kom. & 6,91 & 6,71 & 6,42 & 6,02 & 5,52 \\
8 & Bank \& Lembaga keu. & 0,65 & 0,62 & 0,57 & 0,54 & 0,54 \\
9 & Jasa-jasa & 3,64 & 3,58 & 3,62 & 3,40 & 3,11 \\
\hline
\end{tabular}

Sumber data: BPS Kabupaten Berau

hingga seharusnya porsi pendapatan asli daerah sebagai komponen penerimaan daerah juga meningkat. Peningkatan pendapatan asli daerah yang dianggap sebagai modal, secara akumulasi akan lebih banyak menimbulkan eksternalitas yang bersifat positif dan akan mempercepat pertumbuhan ekonomi (Pujiati, 2008).

Desentralisasi fiskal memberikan kewenangan yang besar kepada daerah untuk menggali potensi yang dimiliki sebagai sumber pendapatan daerah untuk membiayai pengeluaran daerah dalam rangka pelayanan publik. Berdasarkan UndangUndang No. 32 Tahun 2004, salah satu sumber pendapatan daerah adalah Pendapatan Asli Daerah yang terdiri dari hasil pajak daerah, hasil retribusi daerah, hasil pengelolaan kekayaan daerah yang dipisahkan dan lain-lain pendapatan asli daerah yang sah. Peningkatan pendapatan asli daerah diharapkan meningkatkan investasi belanja modal pemerintah daerah sehingga kualitas pelayanan publik semakin baik tetapi yang terjadi adalah peningkatan pendapatan asli daerah tidak diikuti dengan kenaikan anggaran belanja modal yang signifikan hal ini disebabkan karena pendapatan asli daerah tersebut banyak digunakan untuk membiayai belanja lainnya.

Setiap daerah mempunyai kemampuan keuangan yang tidak sama dalam mendanai kegiatan-kegiatannya, hal ini menimbulkan ketimpangan fiskal antara satu daerah dengan daerah lainnya. Oleh karena itu, untuk mengatasi ketimpangan fiskal ini Pemerintah mengalokasikan dana yang bersumber dari APBN untuk mendanai kebutuhan daerah dalam pelaksanaan desentralisasi. Salah satu dana perimbangan dari pemerintah ini adalah Dana Alokasi Umum(DAU) yang pengalokasiannya menekankan aspek pemerataan dan keadilan yang selaras dengan penyelenggaraan urusan pemerintahan (UU 32/2004). Dengan adanya transfer dana dari pusat ini diharapkan pemerintah daerah bisa lebih mengalokasikan pendapatan asli daerah yang didapatnya untuk membiayai belanja modal di daerahnya.

Dana alokasi umum (DAU) adalah dana yang berasal dari APBN (anggaran pendapatan dan belanja Negara) yang dialokasikan dengan tujuan pemerataan kemampuan keuangan antar daerah untukmembiayai kebutuhan pengeluarannya dalam rangka pelaksanaan desentralisasi. Peme- 
Faktor-faktor yang Mempengaruhi Belanja Daerah Serta Dampaknya.... (Elita Herlina)

rintah pusat memberikan bantuan berupa DAU yang besarnya sekurang-kurangnya $26 \%$ dari penerimaan dalam negeri yang ditetapkan dalam APBN. Untuk daerah provinsi merima sebesar $10 \%$ dari DAU yang ditetapkan, sedangkan kabupaten/ kota sebesar $90 \%$. Pengaturan lebih lanjut dituangkan dalam peraturan pemerintah Nomor 104 tahun 2000 yang menyatakan bahwa pembagian DAU kepada seluruh provinsi dan kabupaten/kota di Indonesia berdasarkan bobot masing-masing daerah yang ditetapkan berdasarkan atas kebutuhan wilayah otonomi daerah dan potensi ekonomi daerah.

Pertumbuhan ekonomi tidak lepas dari penduduk sebagai bagian penting penggerak perekonomian. Penduduk berfungsi ganda dalam perekonomian, dalam konteks pasar ia berada pada sisi permintaan maupun penawaran. Di sisi permintaan penduduk adalah konsumen, sumber permintaan barang dan jasa. Dan di sisi penawaran penduduk adalah produsen jika ia sebagai pengusaha, pedagang, atau tenaga kerja. Dalam konteks pembangunan pandangan penduduk terpecah dua ada yang menganggapnya sebagai penghambat pembangunan dan ada pula yang menganggap sebagai pemacu pembangunan.

Simon dalam Todaro (2006) mengatakan bahwa pertumbuhan penduduk bukanlah suatu masalah. Melainkan sebaliknya justru merupakan unsur penting yang berdampak positif dan bermanfaat bagipembangunan ekonomi, baik Negara maju ataupun Negara berkembang. Adam Smith juga berpendapat dengan didukung buktiempiris bahwa pertumbuhan penduduk tinggi akan output melalui penambahan tingkat dan ekspansi pasar baik pasar dalam negeri maupun luar negeri. Penambahan penduduk yang tinggi yang diiringi dengan perubahan teknologi akan mendorong tabungan dan juga penggunaan skala ekonomi di dalam produksi. Artinya semakin besar jumlah penduduk yang diiringi dengan investasi lebih dalam pemberdayaan sumberdaya manusia (SDM) akan mengakibatkan banyak bermunculan ide-ide gagasan baru dan tenaga ahli, dengan demikian akan semakin berkembang teknologi. Selanjutnya dalamjangka panjang penduduk merupakan suatu keuntungan dalam pembangunan ekonomi.

Studi tentang pengaruh pendapatan daerah (local own resources revenue) terhadap pengeluaran daerah sudah banyak dilakukan (misalnya Aziz et al, 2000; Blackly, 1986; Joulfaian \& Mokeerjee, 1990; Legrenzi \& Milas, 2001; Von Furstenberg et al, 1986). Hipotesis yang menyatakan bahwa pendapatan daerah (terutama pajak) akan mempengaruhi anggaran belanjapemerintah daerah dikenal dengan nama tax spend hypothesis (Aziz et al, 2000; Doi, 1998; Von Furstenberg et al 1986).

Pengeluaran pemerintah daerah akan disesuaikan dengan perubahan dalam penerimaan pemerintah daerah atau perubahan pendapatan terjadi sebelum perubahan pengeluaran. Dalam konteks internasional, beberapa penelitian yang telah dilakukan untuk melihat pengaruh pendapatan daerah terhadap belanja (di antaranya adalah Cheng, 1999; Friedman, 1978; Hoover \& Sheffrin, 1992). Cheng (1999) menemukan bahwa hipotesis pajak-belanja berlaku untuk kasus Pemda di beberapa negara Amerika Latin, yakni Kolombia, Republik Dominika, Honduras, dan Paraguay. Friedman (1978) menyatakan bahwa kenaikan dalam pajak akan meningkatkan belanja daerah, sehingga akhirnya akan memperbesar defisit.

Menurut Hoover \& Sheffrin (1992), 
yang secara empiris menemukan adanya perbedaan hubungan dalam dua rentang waktu yang berbeda. Mereka menemukan bahwa untuk sampel data sebelum pertengahan tahun 1960-an pajak berpengaruh terhadap belanja, sementara untuk sampel data sesudah tahun 1960-an pajak dan belanja tidak saling mempengaruhi (causally independent).

Dalam literatur ekonomi dan keuangan daerah, hubungan pendapatan dan belanja daerah didiskusikan secara luas sejak akhir dekade 1950-an dan berbagai hipotesis tentang hubungan tersebut diuji secara empiris (Chang \& Ho, 2002). Sebagian studi menyatakan bahwa pendapatan mempengaruhi belanja, sementara sebagian lainnya menyatakan bahwa belanjalah yang mempengaruhi pendapatan (Aziz, 2000; dan Doi, 1998).

Studi tentang pengaruh transfer atau grants dari Pempus terhadap keputusan pengeluaran atau belanja Pemda sudah berjalan lebih dari 30 tahun (Gamkhar \& Oates, 1996). Secara teoritis, respon tersebut akan mempunyai efek distributif dan alokatif yang tidak berbeda dengan sumber pendanaan lain, misalnya pendapatan pajak daerah (Bradford \& Oates, 1971). Namun, dalam studi empiris hal tersebut tidak selalu terjadi. Artinya, stimulus terhadap pengeluaran daerah yang ditimbulkan oleh transfer atau grants tersebut sering lebih besar dibandingkan dengan stimulus dari pendapatan (pajak) daerah sendiri (flypaper effect).

Holzt-eakin et al (1985) menyatakan bahwa terdapat keterkaitan sangat erat antara transfer dari Pempus dengan belanja Pemerintah daerah. Studi Legrenzi \& Milas (2001), menggunakan sampel municipalities di Italia, menemukan bukti empiris bahwa dalam jangka panjang transfer ber- pengaruh terhadap belanja daerah. Secara spesifik mereka menegaskan bahwa variabel-variabel kebijakan Pemda dalam jangka pendek disesuaikan (adjusted) dengan transfer yang diterima, sehingga memungkinkan terjadinya respon yang nonlinier dan asymmetric.

Gamkhar \& Oates (1996) menganalisa respon Pemda terhadap perubahan jumlah transfer dari pemerintah federal di Amerika Serikat untuk tahun 1953-1991. Mereka menyatakan bahwa pengurangan jumlah transfer (cults in federal grants) menyebabkan penurunan dalam pengeluaran daerah.

Studi Holzt-Eakin et al (1994) menganalisis model maximazing under uncertainty of intertemporal utility funcion dengan menggunakan data runtun waktu selama tahun 1934-1991 untuk mengetahui seberapa jauh pengeluaran daerah dapat dirasionalkan melalui suatu model, di mana keputusan-keputusan didasarkan pada ketersediaan sumberdaya secara permanen, bukan ketersediaan yang sifatnya temporer. Mereka menemukan bahwa semua current spending ditentukan oleh current resources.

Studi Holzt-Eakin et al (1985) menemukan bahwa grants tahun lalu dapat memprediksi belanja tahun ini, namun sebaliknya, belanja tahun lalu tidak dapat memprediksi pendapatan tahun berjalan.

Belanja Daerah sebagaimana dimaksud dalam Peraturan Menteri Dalam Negeri Nomor 13 Tahun 2006 tentang Pedoman Pengelolaan Keuangan Daerah pasal 31 ayat (1) menyebutkan bahwa belanja daerah dipergunakan dalam rangka mendanai pelaksanaan urusan pemerintah yang menjadi kewenangan provinsi atau kabupaten/ kota yang terdiri dari urusan wajib, urusan pilihan dan urusan yang penanganannya dalam ba- 
Faktor-faktor yang Mempengaruhi Belanja Daerah Serta Dampaknya.... (Elita Herlina)

gian atau bidang tertentu yang dapat dilaksanakan bersama antara pemerintah dan pemerintah daerah atau antar pemerintah daerah yang ditetapkan berdasarkan peraturan perundang-undangan.

Belanja daerah dikelompokkan ke dalam belanja tidak langsung dan belanja langsung. Belanja tidak langsung merupakan belanja yang dianggarkan tidak terkait secara langsung dengan pelaksanaan program dan kegiatan. Sementara belanja langsung merupakan belanja yang dianggarkan yang terkait secara langsung dengan pelaksanaan programdankegiatan. Menurut Undang-Undang Nomor 17 Tahun 2003, pendapatan daerah adalah hak pemerintah daerah yang diakui sebagai penambah nilai kekayaan bersih.

Yuwono dkk (2005: 107) menyatakan bahwa pendapatan daerah adalah semua penerimaan kas yang menjadi hak daerah dan diakui sebagai penambahan nilai kekayaan bersih dalam satu tahun anggaran dan tidak perlu dibayar kembali oleh pemerintah. Lebih lanjut Halim(2007:96) menyatakan bahwa belanja daerah sepenuhnya diguanakan untuk konsep pembangunan daerah yang bersangkutan.

Konsep pembangunan berkelanjutan memberikan dampak adanya batas, bukan batas absolut akan tetapi batas yang ditentukan oleh tingkat masyarakat dan organisasi sosial, mengenai sumber daya alam serta kemampuan biosfer menyerap pelbagai pengaruhdari kreativitas manusia. Teknologidan organisasi dapat dikelola dan ditingkatkan guna memberi jalan bagi era baru pembangunan ekonomi.

Beberapa alasan yang melandasi pemikiran bahwa kependudukan merupakan faktor yang sangat strategis dalam kerangka pembangunan nasional, antara lain adalah (Tjiptoherijanto, 2002).
Pertama, kependudukan, atau dalam hal ini adalah penduduk, merupakan pusat dari seluruh kebijaksanaan dan programpembangunan yang dilakukan. Dalam GBHN dengan jelas dikemukakan bahwa penduduk adalah subyek dan obyek pembangunan. Sebagai subyek pembangunan maka penduduk harus dibina dan dikembangkan sehingga mampu menjadipenggerakpembangunan. Sebaliknya, pembangunan juga harus dapat dinikmati oleh penduduk yang bersangkutan. Dengan demikian jelas bahwa pembangunan harus dikembangkan dengan memperhitungkan kemampuan penduduk agar seluruh penduduk dapat berpartisipasi aktif dalam dinamika pembangunan tersebut. Sebaliknya, pembangunan tersebut baru dikatakan berhasiljika mampu meningkatkan kesejahteraan penduduk dalam arti yang luas.

Kedua, keadaan dan kondisi kependudukan yang ada sangat mempengaruhi dinamika pembangunan yang dilakukan oleh pemerintah. Jumlah penduduk yang besar jika diikuti dengan kualitas penduduk yang memadai akan merupakan pendorong bagi pertumbuhan ekonomi. Sebaliknya jumlah penduduk yang besar jika diikuti dengan tingkat kualitas yang rendah, menjadikan penduduk tersebut sebagai beban bagi pembangunan.

Ketiga, dampak perubahan dinamika kependudukan baru akan terasa dalamjangka yang panjang. Karena dampaknya baru terasa dalam jangka waktu yang panjang, sering kali peranan penting penduduk dalam pembangunan terabaikan. Sebagai contoh, beberapa ahli kesehatan memperkirakan bahwa krisis ekonomi dewasa ini akan memberikan dampak negatif terhadap kesehatan seseorang selama 25 tahun ke depan atau satu generasi. Dengan demikian, dapat diba- 
yangkan bagaimana kondisi sumber daya manusia Indonesia pada generasi mendatang, 25 tahun setelah tahun 1997. Demikian pula, hasil program keluarga berencana yang dikembangkan 30 tahun yang lalu (1968), baru dapat dinikmati dalam beberapa tahun terakhir ini.

Peningkatan PAD sebenarnya merupakan akses dari pertumbuhan ekonomi (Saragih, 2003:33). Daerah yang pertumbuhan ekonominya positif mempunyai kemungkinan mendapatkan kenaikan PAD. Pemerintah daerah di dalam membiayai belanja daerahnya, selain dengan menggunakan transfer dari pemerintah pusat, mereka juga menggunakan sumber dananya sendiri yaitu PAD. Daerah yang memiliki tingkat pertumbuhan PAD yang positif mempunyai kemungkinan untuk memiliki pendapatan perkapita yang lebih baik (Harianto dan Adi, 2007). Apabila suatu daerah PADnya meningkat maka dana yang dimiliki pemerintah akan meningkat pula. Peningkatan ini akan menguntungkan pemerintah, karena dapat digunakan untuk memenuhi kebutuhan daerahnya sehingga pertumbuhan ekonomi daerah tersebut meningkat pula.

Basis utama perhitungan DAU adalah kesenjangan fiskal (fiscal gap) atau perbedaan antara kapasitas fiskal dan kebutuhan fiskal di masing-masing daerah. Penelitian yang dilakukan Adi Priyo (2006) membuktikan bahwa PDRB suatu daerah memberikan dampak yang positif terhadap DAU. Hal ini membuktikan bahwa transfer pemerintah dalam bentuk DAU memiliki peran yang penting di dalam perekonomian suatu daerah.

Berdasarkan UU No. 33 Tahun 2004 pengalokasian DAU ditentukan atas besar kecilnya celah fiskal (fiscal gap) suatu daerah, yang merupakan selisih antara kebu- tuhan daerah (fiscal need) dan potensi daerah (fiscal capacity). Apabila suatu daerah memiliki potensi fiskal dan PDRB yang besar tetapi kebutuhan fiskal kecil maka akan memperoleh alokasi DAU yang relatif kecil. Sebaliknya, untuk daerah yang potensi fiskalnya kecil dan PDRB yang kecil sedangkan kebutuhan fiskalnya besar maka akan memperoleh alokasi DAU yang relatif besar.

Tingginya angka rasio beban tanggungan merupakan faktor penghambat pembangunan di negara berkembang termasuk di Indonesia, karena sebagian dari pendapatan yang diperoleh dari golongan produktif, terpakasa harus dikeluarkan untuk memenuhi kebutuhan kelompok yang belum produktif. Negara berkembang dengan tingkat fertilitas tinggi, mempunyai angka rasio beban tanggungan yang tinggi, dikarenakan proporsi anak-anak dalam penduduk tersebut, sebaliknya dengan tanggungan yang kecil akan lebih mudah memobilisasi dana masyarakat dan anggaran pemerintah untuk investasi yang lebih produktif.

Pada negara dengan rasio ketergantungan penduduk yang rendah terjadi proses penghematan bahan makanan dan bahan baku lainnya sekaligus terjadi kulitatif kehidupan penduduk, hal ini selanjutnya akan meningkatkan angka harapan hidup (life expentancy) negara tersebut. Beban ketergantungan yang lebih besar akan mempengaruhi kapasitas negara berkembang untuk menabung dan menanamkan modal (United Nation, 1973), karena di negara berkembang proporsi anak-anak relatif tinggi, maka rasio ketergantungan juga akan lebih tinggi daripada di negara-negara maju. Rendahnya penduduk produktif akan mengurangi total produktifitas negara yang dihitung dengan PDB ataupun PDRB untuk 
Faktor-faktor yang Mempengaruhi Belanja Daerah Serta Dampaknya.... (Elita Herlina)

daerah, sebaliknya alokasi yang tinggi pada penduduk yang tidak produktif merupakan beban tersendiri dalam PDRB.

Iskana (2009) meneliti tentang Pengaruh Belanja dan Pendapatan Terhadap Pertumbuhan Ekonomi, Kemiskinan Dan Pengangguran pada Pemerintahan Kabupaten dan Kota Provinsi Jawa Timur. Hasil penelitian menunjukkan Belanja Daerah tidak berpengaruh signifikan terhadap pertumbuhan ekonomi, belanja daerah berpengaruh positif dan signifikan terhadap kemiskinan, belanja daerah berpengaruh positif dan signifikan terhadap pengangguran.

Pendapatan daerah tidak berpengaruh signifikan terhadap pertumbuhan ekonomi, pendapatan daerah berpengaruh positif dan signifikan terhadap kemiskinan, pendapatan daerah berpengaruh positif dan signifikan terhadap pengangguran. Untuk Pertumbuhan ekonomi tidak berpengaruh signifikan terhadap kemiskinan, pertumbuhan ekonomi berpengaruh positif dan signifikan terhadap pengangguran.

Indonesia telah melakukan kebijakan mengatasi permasalahan kemiskinan yang dilaksanakan oleh pemerintah, akan tetapi fenomena yang terjadi justru menunjukkan bahwa jumlah masyarakat miskin tidak berkurang. Ini membuktikan bahwa hasil pembangunan yang dilakukan selama ini belum memberikan kemakmuran yang merata sehingga terjadi kesenjangan pendapatan. Jika setiap daerah mampu mengoptimalkan berbagai potensi disektor masing-masing, maka dengan sendirinya peningkatan terhadap PAD akan lebih tinggi. Dengan begitu daerah tersebut akan meminimkan tingkat pengangguran di daerahnya dan mengurangi jumlah kemiskinan yang ada di daerah.

Masalah ketimpangan ekonomi antar daerah menjadi suatu masalah yang dilema di Indonesia. Berbagai program yang dikembangkan untuk menjembatani ketimpangan antar daerah selama ini ternyata belum mencapai hasil yang memadai karena di masa mendatang agaknya alokasi anggaran pembangunan sebagai instrumen untuk mengurangi ketimpangan ekonomi. Strategi alokasi anggaran ini bisa mendorong dan mempercepat pertumbuhan ekonomi sekaligus menjadi alat mengurangi kesenjangan/ ketimpangan regional (Kuncoro, 2003:112).

Berdasarkan penjabaran tersebut maka Penelitian ini bertujuan untuk mengidentifikasi pengaruh dari pendapatan asli daerah (PAD), dana alokasi umum (DAU), serta jumlah penduduk terhadap belanja daerah dan PDRB. Sehingga penelitian ini akan mampu memberikan gambaran mengenai kebijakan yang harus diambil pemerintah daerah dalam menetapkan belanja daerah dan besaran PDRB di Kabupaten Berau melalui pendapatan asli daerah, dana alokasi umum dan jumlah penduduk Kabupaten Berau sebagai acuannya.

\section{Metode Penelitian}

Penelitian inimerupakan penelitiankausalitas dan eksplanatif, menjelaskan hubungan timbal balik dan gambaran fenomena dari gambaran yang nyata. Jenis data yang digunakan adalah data skunder dan time series tahun 2002-2011 yang diperoleh dari Badan Pusat Statistik Kabupaten Berau Variabel-variabel yang digunakan dalam penelitian ini terdiri dari dua kelompok variabel yaitu: variabel tidak bebas (dependent variable) yang dalam peneltian ini ditunjukkan oleh PDRB dan belanja daerah (Y) dan penggunaan variabel-variabel bebas (independent variable) (X) yaitu Pendapatan Asli Daerah (PAD), Dana Alokasi Umum (DAU) dan Jumlah Penduduk. 
Ekonomika-Bisnis Vol. 4 No.1 Bulan Januari Tahun 2013. Hal 25-44

Data yang diperoleh dianalisis menggunakan analisis regresi berganda, analisis tersebut digunakan oleh penulis untuk meramalkan bagaimana keadaan (naik turunnya) variabel dependen terhadap dua atau lebih variabel independen. Rumus regrasi berganda dalam penelitian ini adalah sebagai berikut: Persamaan substuktur pertama adalah sebagai berikut (Sunyoto, 2012: 61): $\mathrm{Y}_{1}=\mathrm{b}_{1} \mathrm{Y}_{1} \mathrm{X}_{1}+\mathrm{b}_{2} \mathrm{Y}_{1} \mathrm{X}_{2}+\mathrm{b}_{3} \mathrm{Y}_{1} \mathrm{X}_{3}+\mathrm{E}_{1}$. Keterangan analisis regresi dalam sub struktur pertama ini digunakan untuk menguji pengaruh pendapatan asli daerah, dana alokasi umum dan jumlah penduduk terhadap belanja daerah kabupaten Berau. Penyelesaian model regresi linier berganda dilakukan dengan bantuan Program SPSS for Windows Release 19.0.

Persamaan substuktur kedua adalah sebagai berikut (Sunyoto, 2012: 61): $\mathrm{Y}_{2}=$ $\mathrm{b}_{1} \mathrm{Y}_{2} \mathrm{X}_{1}+\mathrm{b}_{2} \mathrm{Y}_{2} \mathrm{X}_{2}+\mathrm{b}_{3} \mathrm{Y}_{2} \mathrm{X}_{3}+\mathrm{b}_{4} \mathrm{Y}_{2} \mathrm{Y}_{1}+\mathrm{E}_{2}$ Keterangan analisis regresi dalam sub struktur kedua ini digunakan untuk menguji pengaruh pendapatan asli daerah, dana alokasi umum dan jumlah penduduk dan belanja daerah terhadap PDRB. Penyelesaian model regresi linier berganda dilakukan dengan bantuan Program SPSS for Windows Release 19.0.

Upaya untuk melihat gambaran pengaruh vairabel-variabel independen terhadap variabel dependen dalam penelitian ini, diperlukan sebuah rumusan hipotesis yang berfungsi memprediksi hubungan antar variabel atau keterkaitan antar variabel. Maka diperlukan sebuah metode pengujian hipotesis sebagai berikut: 1) Analisis koefisien korelasi dan determinasi, Priyatno (2009:78), "Koefisien ini digunakan untuk menunjukkan seberapa besar hubungan yang terjadi antara variabel independen $\left(\mathrm{X}_{1}, \mathrm{X}_{2}, \ldots \mathrm{X}_{\mathrm{n}}\right)$ secara serentak terhadap variabel dependen
(Y)". Nilai R dapat dicari dengan rumus sebagai berikut:

$$
\text { Ry }=\sqrt{\frac{b_{1} \sum \mathrm{X}_{1} \mathrm{Y}+\mathrm{b}_{2} \sum \mathrm{X}_{2} \mathrm{Y}}{\sum \mathrm{Y}^{2}}}
$$

(Sumber: Sugiyono, 2010:286)

Priyatno (2009:79), “Analisis determinasi dalam regresi berganda digunakan untuk mengetahui persentase sumbangan pengaruh variabel independen $\left(\mathrm{X}_{1}, \mathrm{X}_{2}, \ldots\right.$ $X_{n}$ ) secara serentak terhadap variabel dependen (Y)". Semakin besar nilai $\mathrm{R}^{2}$, maka semakin besar pengaruh antara variabel bebas terhadap variabel terikat. Sedangkan sisanya sebesar $1-\mathrm{R}^{2}$ merupakan besarnya persentase variabel lain (tidak diteliti dalam penelitian ini) mempengaruhi variabel terikat. Nilai $\mathrm{R}^{2}$ dapat dicari dengan rumus sebagai berikut (Sunyoto, 2010:79):

$$
\mathrm{R}^{2}=\frac{\mathrm{b}_{1} \sum \mathrm{X}_{1} \mathrm{Y}+\mathrm{b}_{2} \sum \mathrm{X}_{2} \mathrm{Y}}{\sum \mathrm{Y}^{2}}
$$

Apabila koefisien determinasi $\left(\mathrm{R}^{2}\right)$ mendekati angka satu (1) berarti terdapat hubungan yang kuat (Djarwanto dan Pangestu, 2008:324).

Uji F (Uji Simultan/Serentak) Pengujian ini adalah untuk mengetahui apakah koefisien regresi variable bebas secara bersama-sama berpengaruh atau tidak terhadap variable tidak bebas. Untuk memperoleh hasil Uji F ini, maka digunakan rumus sebagai berikut:

$$
F_{\text {hitung }}=\frac{\frac{R^{2}}{k}}{\frac{\left(1-R^{2}\right)}{n-k-1}}
$$

(Rangkuti, 2003:219)

Uji t (uji secara parsial) Pengujian secara parsial digunakan untuk menguji apakah setiap koefisien regresi variabel bebas 
Faktor-faktor yang Mempengaruhi Belanja Daerah Serta Dampaknya.... (Elita Herlina)

mempunyai pengaruh atau tidak terhadap variabel tidak bebas. Uji t dapat diperoleh dengan rumus (Rangkuti, 2005:165):

$$
t_{\text {hitung }}=\frac{b}{s b}
$$

\section{Hasil Penelitian dan Pembahasan}

Sebelum melakukan uji analisis jalur atau regresi berganda, diperlukan sebuahuji asumsi klasik untuk melihat apakah variabelvariabel yang akan diteliti termasuk dalam variabel yang memiliki kriteria sebagai berikut: a) berdistribusi normal b) bukan variabel multikolinieritas c) bebas dari masalah heterokedasitisitas d) auto korelasi.

Berdasarkan uji asumsi klasik untuk Sub-Struktur 1 menunjukan bahwa datadata dalam penelitian ini mendekati garis normal, Hal ini menunjukkan bahwa semua data yang digunakan dalam penelitian ini merupakan data yang berdistribusi normal. Hasil dari uji Multikolinieritas meunjukan nilai tolerance yang lebih besar dari 0.1 atau nilai VIF (Variance Inflation Factor) kurang dari 10. Hal ini berarti bahwa variabelvariabel bebas dalam penelitian tidak terdapat gejala multikolinearitas. Hasil dari Uji Heteroskedastisitas data tidak membentuk pola yang berarti terbebas dari masalahheterokedastisitas. Hasil olah data dari UjiAutokorelasi menunjukan Durbin Watson test $=$ 2.040 dan DW berada diatas 2 dapat di- simpulkan bahwa data di atas terjadi autokorelasi negatif. data dalam penelitan terjadi autokorelasi negatif.

Hasil uji asumsi klasik untuk SubStuktur 2 menunjukan hasil sebagai berikut: berdasarkan uji normalitas data menujukan data-data dalam penelitian ini mendekati garis normal. Hal ini menunjukkan bahwa semua data yang digunakan dalam penelitian ini merupakan data yang berdistribusi normal. Hasil dari Uji Multikolinieritas menunjukkan nilai tolerance yang lebih besar dari 0.1 atau nilai VIF (Variance Inflation Factor) kurang dari 10. Hal ini berarti bahwa varibel-variabel bebas dalam penelitian tidak terdapat gejala multikolinearitas. Hasil Uji Heteroskedastisitas terlihat bahwa data tidak membentuk suatu pola tertentu. Hal ini berarti model penelitian terbebas dari masalah heterokedastisitas. Hasil Uji Autokorelasi ditemukan Durbin Watson test $=0.931$ dan DW berada diantara -2 dan +2 atau $-2<$ DW $<+2$ dapat disimpulkan bahwa data di atas tidak terjadi autokorelasi.

Bagian ini menguraikan tiap-tiap jalur dalam model dengan menggunakan analisis jalur, dengan penjabaran mengenai sub-struktur pertama dan sub-struktur yang kedua sebagai berikut:

Pada fungsi 1 (sub-struktur-1), variabel eksogen $=X_{1}, X_{2}, X_{3}$ dan variabel endogen $\mathrm{Y}_{1}$ dapat diketahui persamaan sebagai berikut: $\mathrm{Y}_{1}=0.588 \mathrm{X}_{1}+0.108 \mathrm{X}_{2}$

Tabel 2. Nilai koefisien jalur: $X_{1}, X_{2}, X_{3}$, dan $Y_{1}$

\begin{tabular}{|c|c|c|c|c|c|}
\hline \multirow{2}{*}{ Model } & \multicolumn{2}{|c|}{ Unstandardized Coefficients } & \multirow{2}{*}{$\begin{array}{c}\text { Standardized } \\
\text { Coefficients } \\
\text { Beta }\end{array}$} & \multirow[t]{2}{*}{$\mathrm{t}$} & \multirow[t]{2}{*}{ Sig. } \\
\hline & B & Std. Error & & & \\
\hline (Constant) & -1338256.472 & 1358506.934 & & -.985 & .363 \\
\hline $\mathrm{X} 1$ & 7.832 & 4.111 & .588 & 1.905 & .105 \\
\hline $\mathrm{X} 2$ & .913 & 1.865 & .108 & .490 & .642 \\
\hline X3 & 11.103 & 9.745 & .298 & 1.139 & .298 \\
\hline
\end{tabular}

Sumber: Output SPSS. 
Ekonomika-Bisnis Vol. 4 No.1 Bulan Januari Tahun 2013. Hal 25-44

+ 0.298 X 3 Berdasarkan model path yang telah dihasilkan di atas, selanjutnya dapat diinterprestasikan sebagai berikut: Koefisien $\operatorname{PAD}\left(\mathrm{X}_{1}\right)$ sebesar 0.588 , artinya pengaruh $\operatorname{PAD}\left(\mathrm{X}_{1}\right)$ secara langsung terhadap belanja daerah $\left(\mathrm{Y}_{1}\right)$ sebesar 0.588. Koefisien DAU $\left(\mathrm{X}_{2}\right)$ sebesar 0.108 , artinya pengaruh DAU $\left(\mathrm{X}_{2}\right)$ secara langsung terhadap belanja daerah $\left(\mathrm{Y}_{1}\right)$ sebesar 0.108. Koefisien jumlah penduduk $\left(\mathrm{X}_{3}\right)$ sebesar 0.298 , artinya pengaruh jumlah penduduk $\left(\mathrm{X}_{3}\right)$ secara langsung terhadap belanja daerah $\left(\mathrm{Y}_{1}\right)$ sebesar 0.298 .

Pada fungsi 2 (sub-struktur-2), variabel eksogen $=X_{1}, X_{2}, X_{3}, Y_{1}$ dan variabel endogen $\mathrm{Y}_{2}$ dapat diketahui persamaan sebagai berikut: $\mathrm{Y}_{2}=0.663 \mathrm{X}_{1}+0.029 \mathrm{X}_{2}+$ $0.882 \mathrm{X}_{3}-0.649 \mathrm{Y}_{1}$ Berdasarkan model path yang telah dihasilkan tersebut, selanjutnya dapat diinterprestasikan sebagai berikut: Koefisien $\operatorname{PAD}\left(\mathrm{X}_{1}\right)$ sebesar 0.663 , artinya pengaruh $\mathrm{PAD}\left(\mathrm{X}_{1}\right)$ secara langsung terhadap PDRB $\left(\mathrm{Y}_{2}\right)$ sebesar 0.663. Koefisien DAU $\left(\mathrm{X}_{2}\right)$ sebesar 0.029, artinya pengaruh DAU $\left(\mathrm{X}_{2}\right)$ secara langsung terhadap PDRB $\left(\mathrm{Y}_{2}\right)$ sebesar 0.029. Koefisien jumlah penduduk $\left(\mathrm{X}_{3}\right)$ sebesar 0.882 , artinya pengaruh jumlah penduduk $\left(\mathrm{X}_{3}\right)$ secara langsung terhadap PDRB $\left(\mathrm{Y}_{2}\right)$ sebesar 0.882. Koefisien belanja daerah $\left(\mathrm{Y}_{1}\right)$ sebesar -0.649 , artinya pengaruh belanja daerah $\left(\mathrm{Y}_{1}\right)$ secara langsung terhadap PDRB $\left(\mathrm{Y}_{2}\right)$ sebesar -0.649.

Untuk mengetahui keeratan hubungan antara variabel independent terhadap dependent dapat dilihat dari nilai koefisien kolerasi (R) serta analisis koefisien determinasi $\left(\mathrm{R}^{2}\right)$ digunakan untuk menunjukkan proporsi variabel dependen yang dijelaskan oleh variabel independen. Nilai $R$ dan $\mathrm{R}^{2}$ yang diperoleh dijelaskan pada tabel4.

Berdasarkan hasil data didapatkan nilai koefisien korelasi sebesar 0,950. Hal ini berarti terdapat hubungan antara PAD,

Tabel 3. Nilai koefisien jalur: $\mathrm{X}_{1}, \mathrm{X}_{2}, \mathrm{X}_{3}, \mathrm{Y}_{1}$ dan $\mathrm{Y}_{2}$

\begin{tabular}{lrrrrr}
\hline \multirow{2}{*}{ Model } & \multicolumn{2}{c}{ Unstandardized Coefficients } & $\begin{array}{c}\text { Standardized } \\
\text { Coefficients } \\
\text { Beta }\end{array}$ & \multicolumn{1}{c}{$\mathrm{t}$} & \multicolumn{1}{c}{ Sig. } \\
\cline { 2 - 3 } (Constant) & \multicolumn{1}{c}{$\mathrm{B}$} & \multicolumn{1}{c}{ Std. Error } & & & \\
X1 & 9.721 & 7.147 & .663 & 1.360 & .232 \\
X2 & .266 & 2.610 & .029 & .102 & .923 \\
X3 & 36.240 & 14.747 & .882 & 2.457 & .057 \\
Y1 & -.715 & .560 & -.649 & -1.276 & .258 \\
\hline
\end{tabular}

Sumber: Output SPSS.

Tabel 4. Analisis koefisien korelasi dan koefisien determinasi untuk variabel penelitian $\mathrm{X}_{1}, \mathrm{X}_{2}, \mathrm{X}_{3}$ dan $\mathrm{Y}_{1}$.

\begin{tabular}{|c|c|c|c|c|}
\hline Model & $\mathrm{R}$ & R Square & Adjusted R Square & $\begin{array}{l}\text { Std. Error of the } \\
\text { Estimate }\end{array}$ \\
\hline 1 & $.950^{\mathrm{a}}$ & .902 & .852 & 269219.4980 \\
\hline
\end{tabular}

Sumber: Output SPSS. 
Faktor-faktor yang Mempengaruhi Belanja Daerah Serta Dampaknya.... (Elita Herlina)

DAU, jumlah penduduk dengan belanja daerah dengan tingkat hubungan sangat kuat karena berada diinterval koefisien 0.8001.000. Sedangkan koefisien determinasi $\left(\mathrm{R}^{2}\right)$ sebesar 0,902 artinya bahwa $90.20 \%$ variasi dari variabel belanja daerah dapat dijelaskan oleh PAD, DAU, jumlah penduduk, sedangkan $9.80 \%$ lainnya dijelaskan oleh variabel lain yang tidak masuk dalam variabel yang diteliti.

Berdasarkan hasil data tabel 5 didapatkan nilai koefisien korelasi sebesar 0,934. Hal ini berarti terdapat hubungan antara PAD, DAU, jumlah penduduk dan belanja daerah dengan PDRB dengan tingkat hubungan sangat kuat karena berada di interval koefisien 0.800-1.000. Sedangkan koefisien determinasi $\left(\mathrm{R}^{2}\right)$ sebesar 0,873 ar- tinya bahwa $87.30 \%$ variasi dari variabel PDRB dapat dijelaskan oleh PAD, DAU, jumlah penduduk dan belanja daerah sedangkan $12.70 \%$ lainnya dijelaskan oleh variabel lain yang tidak masuk dalam variabel yang diteliti.

Pengujian ini untuk mengetahui adanya pengaruh variabel eksogen $=X_{1}, X_{2}, X_{3}$ terhadap variabel endogen $\mathrm{Y}_{1}$ dan mengetahui adanya pengaruh variabel eksogen $=$ $\mathrm{X}_{1}, \mathrm{X}_{2}, \mathrm{X}_{3}$ terhadap variabel endogen $\mathrm{Y}_{2}$ serta mengetahui pengaruh variabel eksogen $=\mathrm{X}_{1}, \mathrm{X}_{2}, \mathrm{X}_{3}, \mathrm{Y}_{1}$ terhadap variabel endogen $\mathrm{Y}_{2}$ hasil pengujian secara simultan pada tabel 7.

Tabel 7 menunjukkan bahwa secara keseluruhan pada taraf signifikan $(\alpha)$ 10\% pada tabel ANOVA terlihat nilai signifikansi

Tabel 5. Analisis koefisien korelasi dan koefisien determinasi untuk variabel penelitian $\mathrm{X}_{1}, \mathrm{X}_{2}, \mathrm{X}_{3}, \mathrm{Y}_{1}$ dan $\mathrm{Y}_{2}$.

\begin{tabular}{rrrrr}
\hline Model & R & R Square & Adjusted R Square & \multicolumn{2}{c}{$\begin{array}{c}\text { Std. Error of the } \\
\text { Estimate }\end{array}$} \\
\hline 1 & $.934^{\mathrm{a}}$ & .873 & .771 & 269423.8125 \\
\hline
\end{tabular}

Sumber: Output SPSS.

Tabel 6. Hasil Analisis Uji F (Uji Simultan) variabel eksogen $=X_{1}, X_{2}, X_{3}$ terhadap variabel endogen $\mathrm{Y}_{1}$.

\begin{tabular}{|c|c|c|c|c|c|c|}
\hline & Model & $\begin{array}{l}\text { Sum of } \\
\text { Squares }\end{array}$ & Df & $\begin{array}{c}\text { Mean } \\
\text { Square }\end{array}$ & $\mathrm{F}$ & Sig. \\
\hline \multirow[t]{3}{*}{1} & Regression & $3.987 \mathrm{E} 12$ & 3 & $1.329 \mathrm{E} 12$ & 18.337 & $002^{\mathrm{a}}$ \\
\hline & Residual & 4.349E11 & 6 & $7.248 \mathrm{E} 10$ & & \\
\hline & Total & 4.422E12 & 9 & & & \\
\hline
\end{tabular}

Sumber: Output SPSS.

Tabel 7. Hasil Analisis Uji F (Uji Simultan) variabel eksogen $=X_{1}, X_{2}, X_{3}, Y_{1}$ terhadap variabel endogen $\mathrm{Y}_{2}$.

\begin{tabular}{llcrllr}
\hline & Model & $\begin{array}{c}\text { Sum of } \\
\text { Squares }\end{array}$ & Df & $\begin{array}{c}\text { Mean } \\
\text { Square }\end{array}$ & F & \multicolumn{2}{c}{ Sig. } \\
\hline 1 & Regression & $4.686 \mathrm{E} 12$ & 4 & $1.172 \mathrm{E} 12$ & 8.584 & $.018^{\mathrm{a}}$ \\
& Residual & $6.824 \mathrm{E} 11$ & 5 & $1.365 \mathrm{E} 11$ & & \\
& Total & $5.368 \mathrm{E} 12$ & 9 & & & \\
\hline
\end{tabular}

Sumber: Output SPSS. 
Ekonomika-Bisnis Vol. 4 No.1 Bulan Januari Tahun 2013. Hal 25-44

0,002 lebih kecil dibandingkan dengan $10 \%$ (0.05) untuk seluruh variabel, dengan demikian dapat diambil kesimpulan bahwa secara bersama-sama eksogen $=X_{1}, X_{2}$, $\mathrm{X}_{3}$ berpengaruh secara signifikan terhadap variabel endogen $\mathrm{Y}_{1}$

Tabel 7 menunjukkan bahwa secara keseluruhan pada taraf signifikan $(\alpha) 10 \%$ pada tabelANOVA terlihat nilai signifikansi 0,018 lebih kecil dibandingkan dengan $10 \%$ (0.05) untuk seluruh variabel, dengan demikian dapat diambil kesimpulan bahwa secara bersama-sama variabel eksogen $=X_{1}$, $\mathrm{X}_{2}, \mathrm{X}_{3}, \mathrm{Y}_{1}$ tidak berpengaruh secara signifikan terhadap variabel endogen $\mathrm{Y}_{2}$.

Pengujian ini untuk mengetahui adanya pengaruh variabel eksogen $=X_{1}, X_{2}, X_{3}$ terhadap variabel endogen $\mathrm{Y}_{1}$ dan mengetahui adanya pengaruh variabel eksogen $=X_{1}$,
$\mathrm{X}_{2}, \mathrm{X}_{3}$ terhadap variabel endogen $\mathrm{Y}_{2}$ serta mengetahui pengaruh variabeleksogen $=X_{1}$, $\mathrm{X}_{2}, \mathrm{X}_{3}, \mathrm{Y}_{1}$ terhadap variabel endogen $\mathrm{Y}_{2}$ hasil pengujian secara parsial dapat dilihat pada tabel 8 .

Tabel 8 dapat dijelaskan sebagai berikut: Pada level of significant 0,10 , diperoleh signifikan t untuk variabel PAD $\left(\mathrm{X}_{1}\right)$, sebesar 0.105, Dengan demikian variabel PAD $\left(X_{1}\right)$ terbukti tidak berpengaruh signifikan terhadap variabel belanja daerah $\left(\mathrm{Y}_{1}\right)$. Pada level of significant 0,10 , diperoleh signifikan $\mathrm{t}$ untuk variabel DAU $\left(\mathrm{X}_{2}\right)$, sebesar 0.642 Dengan demikian variabel DAU $\left(\mathrm{X}_{2}\right)$ terbukti tidak berpengaruh signifikan terhadap variabel belanja daerah $\left(\mathrm{Y}_{1}\right)$. Pada level of significant 0,10 , diperoleh signifikan t untuk jumlah penduduk $\left(\mathrm{X}_{3}\right)$, sebesar 0.298 Dengan demikian vari-

Tabel 8. Hasil Analisis Uji t (Uji Parsial) variabel eksogen $=\mathrm{X}_{1}, \mathrm{X}_{2}, \mathrm{X}_{3}$ terhadap variabel endogen $\mathrm{Y}_{1}$.

\begin{tabular}{|c|c|c|c|c|c|}
\hline \multirow{2}{*}{ Model } & \multicolumn{2}{|c|}{ Unstandardized Coefficients } & \multirow{2}{*}{$\begin{array}{c}\text { Standardized } \\
\text { Coefficients } \\
\text { Beta }\end{array}$} & \multirow{2}{*}{$\mathrm{t}$} & \multirow{2}{*}{ Sig. } \\
\hline & B & Std. Error & & & \\
\hline (Constant) & -1338256.472 & 1358506.934 & & -.985 & .363 \\
\hline $\mathrm{X} 1$ & 7.832 & 4.111 & .588 & 1.905 & .105 \\
\hline $\mathrm{X} 2$ & .913 & 1.865 & .108 & .490 & .642 \\
\hline X3 & 11.103 & 9.745 & .298 & 1.139 & .298 \\
\hline
\end{tabular}

Sumber: Output SPSS.

Tabel 9. Hasil Analisis Uji t (Uji Parsial) variabel eksogen $=\mathrm{X}_{1}, \mathrm{X}_{2}, \mathrm{X}_{3}, \mathrm{Y}_{1}$ terhadap variabel endogen $\mathrm{Y}_{2}$.

\begin{tabular}{|c|c|c|c|c|c|}
\hline \multirow{2}{*}{ Model } & \multicolumn{2}{|c|}{ Unstandardized Coefficients } & \multirow{2}{*}{$\begin{array}{c}\text { Standardized } \\
\text { Coefficients } \\
\text { Beta }\end{array}$} & \multirow[t]{2}{*}{$\mathrm{t}$} & \multirow{2}{*}{ Sig. } \\
\hline & B & Std. Error & & & \\
\hline (Constant) & -2604713.728 & 2009248.964 & & -1.296 & .251 \\
\hline $\mathrm{X} 1$ & 9.721 & 7.147 & .663 & 1.360 & .232 \\
\hline $\mathrm{X} 2$ & .266 & 2.610 & .029 & .102 & .923 \\
\hline $\mathrm{X} 3$ & 36.240 & 14.747 & .882 & 2.457 & .057 \\
\hline Y1 & -.715 & .560 & -.649 & -1.276 & .258 \\
\hline
\end{tabular}

Sumber: Output SPSS. 
Faktor-faktor yang Mempengaruhi Belanja Daerah Serta Dampaknya.... (Elita Herlina)

abel jumlah penduduk $\left(\mathrm{X}_{3}\right)$ terbukti tidak berpengaruh signifikan terhadap variabel belanja daerah $\left(\mathrm{Y}_{1}\right)$.

Tabel 9 dapat dijelaskan sebagai berikut: Pada level of significant 0,10 , diperoleh signifikan $t$ untuk variabel PAD $\left(\mathrm{X}_{1}\right)$, sebesar 0.232 Dengan demikian variabel $\operatorname{PAD}\left(\mathrm{X}_{1}\right)$ terbukti tidak berpengaruh signifikan terhadap variabel PDRB $\left(\mathrm{Y}_{2}\right)$. Pada level of significant 0,10 , diperoleh sigifikan t untuk variabel DAU $\left(\mathrm{X}_{2}\right)$, sebesar 0.923 Dengan demikian variabel DAU $\left(\mathrm{X}_{2}\right)$ terbukti tidak berpengaruh signifikan terhadap variabel PDRB $\left(\mathrm{Y}_{2}\right)$. Pada level of significant 0,10 , diperoleh signifikan $t$ untuk variabel jumlah penduduk $\left(\mathrm{X}_{3}\right)$, sebesar 0.057 Dengan demikian variabel jumlah penduduk $\left(\mathrm{X}_{3}\right)$ terbukti berpengaruh signifikan terhadap variabel PDRB $\left(\mathrm{Y}_{2}\right)$. Pada level of significant 0,10 , diperoleh signifikan $t$ untuk variabel belnaja daerah $\left(\mathrm{Y}_{1}\right)$, sebesar 0.258 Dengan demikian variabel belanja daerah $\left(\mathrm{Y}_{1}\right)$ terbukti tidak berpengaruh signifikan terhadap variabel PDRB $\left(\mathrm{Y}_{2}\right)$.
Untuk persamaan substruktur pertama: $\mathrm{Y}_{1}=0.588 \mathrm{X}_{1}+0.108 \mathrm{X}_{2}+0.298$ $\mathrm{X}_{3}+9.80 \%$, Dimana: $\mathrm{E}_{1}=1-\mathrm{R}$ square $=$ $1-0.902=0.980=9.80 \%$.

Untuk persamaan substruktur kedua: $\mathrm{Y}_{2}=0.663 \mathrm{X}_{1}+0.029 \mathrm{X}_{2}+0.882 \mathrm{X}_{3}$ $0.649 \mathrm{Y}_{1}+12.70 \%$, Dimana: $\mathrm{E}_{2}=1-\mathrm{R}$ square $=1-0.873=0.127=12.70 \%$

Berdasarkan persamaan substruktur pertama dapat diketahui bahwa pendapatan asli daerah, dana alokasi umum dan jumlah penduduk memberikan pengaruh langsung terhadap belanja daerah dengan estimasi angka sebagai berikut: Pengaruh langsung pendapatan asli daerah (PAD) terhadap belanja daerah sebesar 0.588 . Pengaruh langsung dana alokasi umum (DAU) terhadap belanja daerah sebesar 0.108. Pengaruh langsung jumlah penduduk terhadap belanja daerah sebesar 0.298.

Berdasarkan persamaan substruktur kedua dapat diketahui bahwa pendapatan asli daerah, dana alokasi umum dan jumlah penduduk serta belanja daerah memberikan

Tabel 10. Pengaruh Langsung, Pengaruh Tidak Langsung dan Pengaruh total.

\begin{tabular}{ccccccc}
\hline \multirow{2}{*}{ No } & \multicolumn{2}{c}{ Direct Effect } & \multicolumn{2}{c}{ Indirect Effect } & \multicolumn{2}{c}{ Total Effect } \\
\cline { 2 - 7 } & Variabel & Nilai & Variabel & Nilai & Variabel & Nilai \\
\hline 1 & $\mathrm{X}_{1}-\mathrm{Y}_{1}$ & 0.588 & $\mathrm{X}_{1}-\mathrm{Y}_{1}-\mathrm{Y}_{2}$ & -0.382 & $\mathrm{X}_{1}-\mathrm{Y}_{1}-\mathrm{Y}_{2}$ & -0.061 \\
2 & $\mathrm{X}_{2}-\mathrm{Y}_{1}$ & 0.108 & $\mathrm{X}_{2}-\mathrm{Y}_{1}-\mathrm{Y}_{2}$ & -0.070 & $\mathrm{X}_{2}-\mathrm{Y}_{1}-\mathrm{Y}_{2}$ & -0.541 \\
3 & $\mathrm{X}_{3}-\mathrm{Y}_{1}$ & 0.298 & $\mathrm{X}_{3}-\mathrm{Y}_{1}-\mathrm{Y}_{2}$ & -0.193 & $\mathrm{X}_{3}-\mathrm{Y}_{1}-\mathrm{Y}_{2}$ & -0.351 \\
4 & $\mathrm{X}_{1}-\mathrm{Y}_{2}$ & 0.663 & & & $\mathrm{X}_{1}-\mathrm{Y}_{2}$ & 0.663 \\
5 & $\mathrm{X}_{2}-\mathrm{Y}_{2}$ & 0.029 & & & $\mathrm{X}_{2}-\mathrm{Y}_{2}$ & 0.029 \\
6 & $\mathrm{X}_{3}-\mathrm{Y}_{2}$ & 0.882 & & & $\mathrm{X}_{3}-\mathrm{Y}_{2}$ & 0.882 \\
7 & $\mathrm{Y}_{1}-\mathrm{Y}_{2}$ & -0.649 & & & $\mathrm{Y}_{1}-\mathrm{Y}_{2}$ & -0.649 \\
\hline
\end{tabular}

Sumber: Hasil Penelitian, 2013. 
pengaruh langsung terhadap PDRB dengan estimasi angka sebagai berikut: Pengaruhlangsung pendapatan asli daerah (PAD) terhadap PDRB sebesar 0.663. Pengaruh langsung dana alokasi umum (DAU) terhadap PDRB sebesar 0.029. Pengaruh langsung jumlah penduduk terhadap PDRB sebesar 0.0.882. Pengaruh langsung belanja daerah terhadap PDRB sebesar -0.649.

Berdasarkan persamaan substruktur pertama dan substruktur kedua diperolehpengaruh tidak langsung variabel pendapatan asli daerah, dana alokasi umum dan jumlah penduduk terhadap PDRB melalui belanja daerah sebagai berikut: Pengaruh tidak langsung pendapatan asli daerah (PAD) terhadap PDRB melalui belanja daerah sebesar $0.588 \times-0.649=-0.382$. Pengaruh tidak langsung dana alokasiumum (DAU) terhadap PDRB melalui belanja daerah sebesar $0.029 \times-0.649=-0.070$. Pengaruh tidak langsung jumlah penduduk terhadap PDRB melalui belanja daerah sebesar $0.882 \mathrm{x}$ $0.649=-0.193$.

Hasil penelitian menunjukkan bahwa masing-masing variabel eksogen yang terdiri dari pendapatan asli daerah (PAD), dana alokasi umum (DAU) dan jumlah penduduk memberikan pengaruh terhadap variabel endogen yang terdiri dari belanja daerah dan PDRB dengan penjelasan sebagai berikut: Pertama, Pengaruh pendapatan asli daerah terhadap belanja daerah. Berdasarkan uji secara parsial untuk variabel PAD terbukti tidak berpengaruh signifikan terhadap variabel belanja daerah, sehingga hasil penelitian bertentangan dengan teori tentang tax spend hypothesis atau pendapatan daerah (terutama pajak) akan mempengaruhi anggaran belanja pemerintah (Aziz et al, 2000; Doi, 1998; Von Furstenberg et al 1986). Dalam hal ini pengeluaran pemerin- tah daerah akan disesuaikan dengan perubahan dalam penerimaan pemerintah daerah atau perubahan pendapatan terjadi sebelum perubahan pengeluaran.

Dalam konteks internasional, beberapa penelitian yang telah dilakukan untuk melihat pengaruh pendapatan daerah terhadap belanja (di antaranya adalah Cheng, 1999; Friedman, 1978; Hoover \& Sheffrin, 1992). Cheng (1999) menemukan bahwa hipotesis pajak-belanja berlaku untuk kasus Pemda dibeberapa negara Amerika Latin, yakni Kolombia, Republik Dominika, Honduras, dan Paraguay. Friedman (1978) menyatakan bahwa kenaikan dalam pajak akan meningkatkan belanja daerah, sehingga akhirnya akan memperbesar defisit.

Menurut Hoover \& Sheffrin (1992), yang secara empiris menemukan adanyaperbedaan hubungan dalam dua rentang waktu yang berbeda. Mereka menemukan bahwa untuk sampel data sebelum pertengahan tahun 1960-an pajak berpengaruh terhadap belanja, sementara untuk sampel data sesudah tahun 1960-an pajak dan belanja tidak saling mempengaruhi (causally independent).

Pengaruh dana alokasi umum terhadap belanja daerah. Berdasarkan uji secara parsial variabel DAU terbukti tidak berpengaruh signifikan terhadap variabel belanja daerah. Hasil penelitian sesuai dengan teori yang ada. Secara teoritis, respon tersebut akan mempunyai efek distributif dan alokatif yang tidak berbeda dengan sumber pendanaan lain, misalnya pendapatan pajak daerah (Bradford \& Oates, 1971). Namun, dalam studi empiris hal tersebut tidak selalu terjadi.

Stimulus terhadap pengeluaran daerah yang ditimbulkan oleh transfer atau grants tersebut sering lebih besar dibandingkan de- 
Faktor-faktor yang Mempengaruhi Belanja Daerah Serta Dampaknya.... (Elita Herlina)

ngan stimulus dari pendapatan (pajak) daerah sendiri (flypaper effect). Holzt-eakin et al (1985) menyatakan bahwa terdapat keterkaitan sangat erat antara transfer dari Pempus dengan belanja Pemerintah daerah.

Studi Legrenzi \& Milas (2001), menggunakan sampel municipalities di Italia, menemukan bukti empiris bahwa dalam jangka panjang transfer berpengaruh terhadap belanja daerah. Secara spesifik mereka menegaskan bahwa variabel-variabel kebijakan Pemda dalam jangka pendek disesuaikan (adjusted) dengan transfer yang diterima, sehingga memungkinkan terjadinya respon yang non-linier dan asymmetric.

Gamkhar \& Oates (1996) menganalisa respon Pemda terhadap perubahan jumlah transfer dari pemerintah federal di Amerika Serikat untuk tahun 1953-1991. Mereka menyatakan bahwa pengurangan jumlah transfer (cults in federal grants) menyebabkan penurunan dalam pengeluaran daerah. Studi Holzt-Eakin et al (1994) menganalisis model maximazing under uncertainty of intertemporal utility function dengan menggunakan data runtun waktu selama tahun 1934-1991 untuk mengetahui seberapa jauh pengeluaran daerah dapat dirasionalkan melalui suatu model, di mana keputusan-keputusan didasarkan pada ketersediaan sumberdaya secara permanen, bukan ketersediaan yang sifatnya temporer. Mereka menemukan bahwa semua current spending ditentukan oleh current resources.

Studi Holzt-Eakin et al (1985) menemukan bahwa grants tahun lalu dapat memprediksi belanja tahun ini, namun sebaliknya, belanja tahun lalu tidak dapat memprediksi pendapatan tahun berjalan.

Kedua, Pengaruh jumlah penduduk terhadap belanja daerah. Berdasarkan uji secara parsial variabel jumlah penduduk terbukti tidak berpengaruh signifikan terhadap variabel belanja daerah. Hasil penelitian tidak sesuai dengan hasil penelitian Halim (2007:96) menyatakan bahwa belanja daerah sepenuhnya diguanakn untuk konsep pembangunan daerah yang bersangkutan.

Konsep pembangunan berkelanjutan memberikan dampak adanya batas, bukan batas absolut akan tetapi batas yang ditentukan oleh tingkat masyarakat dan organisasi sosial, mengenai sumber daya alam serta kemampuan biosfer menyerap berbagai pengaruh dari kreativitas manusia. Teknologi dan organisasi dapat dikelola dan ditingkatkan guna memberi jalan bagi era baru pembangunan ekonomi. Beberapa alasan yang melandasi pemikiran bahwa kependudukan merupakan faktor yang sangat strategis dalam kerangka pembangunan nasional, antara lain adalah (Tjiptoherijanto, 2002).

Ketiga, Pengaruh pendapatan asli daerah terhadap PDRB. Berdasarkan uji secara parsial variabel PAD terbukti tidak berpengaruh signifikan terhadap variabel PDRB. Hasil penelitian ini tidak sesuai dengan teori yang menyatakan bahwa Peningkatan PAD sebenarnya merupakan akses dari pertumbuhan ekonomi (Saragih, 2003:33).

Daerah yang pertumbuhan ekonominya positif mempunyai kemungkinan mendapatkan kenaikan PAD. Pemerintah daerah di dalam membiayai belanja daerahnya, selain dengan menggunakan transfer dari pemerintah pusat, mereka juga menggunakan sumber dananya sendiri yaitu PAD.

Daerah yang memiliki tingkat pertumbuhan PAD yang positif mempunyai kemungkinan untuk memiliki pendapatan 
Ekonomika-Bisnis Vol. 4 No.1 Bulan Januari Tahun 2013. Hal 25-44

perkapita yang lebih baik (Harianto dan Adi, 2007). Apabila suatu daerah PAD-nya meningkat maka dana yang dimiliki pemerintah akan meningkat pula. Peningkatan ini akan menguntungkan pemerintah, karena dapat digunakan untuk memenuhikebutuhan daerahnya sehingga pertumbuhan ekonomi daerah tersebut meningkat pula.

Pengaruh dana alokasi umum terhadap PDRB. Berdasarkan uji secara parsial variabelDAU terbuktitidak berpengaruh signifikan terhadap variabel PDRB. Hasil penelitian sejalan dengan penelitian yang dilakukan oleh Adi Priyo (2006) membuktikan bahwa PDRB suatu daerah memberikan dampak yang positif terhadap PAD. Hal ini membuktikan bahwa PAD dan transfer pemerintah dalam bentuk DAU memiliki peran yang penting di dalam perekonomian suatu daerah.

Berdasarkan UU No. 33 Tahun 2004 pengalokasian DAU ditentukan atas besar kecilnya celah fiskal (fiscal gap) suatu daerah, yang merupakan selisih antara kebutuhan daerah (fiscal need) dan potensi daerah (fiscal capacity). Apabila suatu daerah memiliki potensi fiskal dan PDRB yang besar tetapi kebutuhan fiskal kecil maka akan memperoleh alokasi DAU yang relatif kecil.

Keempat, Pengaruh jumlah penduduk terhadap PDRB. Berdasarkan uji secaraparsial variabel jumlah penduduk terbukti berpengaruh signifikan terhadap variabel PDRB. Hasil penelitian menunjukkan bahwa adanya jumlah penduduk yang tinggi dengan rasio ketergantungan penduduk yang rendah terjadi proses penghematan bahan makanan dan bahan baku lainnya sekaligus terjadi kulitatif kehidupan penduduk, hal ini selanjutnya akan meningkatkan angka harapan hidup (life expentancy).
Beban ketergantungan yang lebih besar akan mempengaruhi kapasitas untuk menabung dan menanamkan modal (United Nation, 1973), karena berkembang proporsi anak-anak relatif tinggi, maka rasio ketergantungan juga akan lebih tinggi. Rendahnya penduduk produktif akan mengurangi total produktifitas yang dihitung dengan PDRB untuk daerah, sebaliknya alokasi yang tinggi pada penduduk yang tidak produktif merupakan beban tersendiri dalam PDRB.

Kelima, Pengaruh belanja daerah terhadap PDRB. Berdasarkan uji secara parsial variabel belanja daerah terbukti tidak berpengaruh signifikan terhadap variabel PDRB. Hasil penelitian ini sejalan dengan penelitian yang dilakukan oleh Iskana (2009), Hasil penelitian menunjukkan Belanja Daerah tidak berpengaruh signifikan terhadap pertumbuhan ekonomi.

Jika setiap daerah mampu mengoptimalkan berbagai potensi di sektor masingmasing, maka dengan sendirinya peningkatan terhadap pendapatan akan lebih tinggi. Dengan begitu daerah tersebut akan meminimkan tingkat pengangguran di daerahnya dan mengurangijumlah kemiskinan yang ada di daerah.

Masalah ketimpangan ekonomi antar daerah menjadi suatu masalah yang dilema di Indonesia. Berbagai program yang dikembangkanuntuk menjembataniketimpangan antar daerah selama ini ternyata belum mencapai hasil yang memadai karena di masa mendatang agaknya alokasi anggaran pembangunan sebagai instrumen untuk mengurangi ketimpangan ekonomi.

Strategi alokasi anggaran ini bisa mendorong dan mempercepat pertumbuhan ekonomi sekaligus menjadi alat mengurangi kesenjangan atau ketimpangan regional (Kuncoro, 2003:112). 
Faktor-faktor yang Mempengaruhi Belanja Daerah Serta Dampaknya.... (Elita Herlina)

\section{Penutup}

Pendapatan asli daerah (PAD), dana alokasi umum(DAU) dan jumlah penduduk berpengaruh secara langsung dan tidak signifikan terhadap belanja daerah di Kabupaten Berau dengan nilai masing-masing sebesar 0.588, 0.108 dan 0.298. Pendapatan asli daerah (PAD) dan dana alokasi umum (DAU) berpengaruh secara langsung dan tidak signifikan terhadap PDRB di Kabupaten Berau dengan nilai masing-masing sebesar 0.663 dan 0.029 , sedangkan jumlah penduduk berpengaruh secara langsung dan signifikan terhadap PDRB dengan nilai sebesar 0.882. Belanja daerah berpengaruh langsung dan tidak terhadap PDRB di Kabupaten Berau dengan nilai sebesar -0.649.

Pendapatan asli daerah (PAD), dana alokasi umum(DAU) dan jumlah penduduk berpengaruh secara tidak langsung dan tidak signifikan terhadap PDRB melalui belanja daerah di Kabupaten Berau dengan nilai masing-masing sebesar - 0.382 untuk PAD, 0.070 untuk DAU dan 0.193 unutk jumlah penduduk. Variabel yang berpengaruh dominan terhadap belanja daerah adalah Pendapatan asli daerah (PAD) dengan nilai sebesar 0.588 sedangkan variabel yang berpengaruh dominan terhadap PDRB adalah jumlah penduduk dengan nilai sebesar 0.882 .

\section{DAFTAR PUSTAKA}

Anonim. 1999. Undang-Undang Nomor 22 Tahun 1999 tentang Pemerintah Daerah.

2001. Undang-Undang Nomor 25 Tahun 1999 Tentang Perimbangan Keuangan antara Pemerintah Pusat dan Pemerintah Daerah.

2004. Undang-Undang
Nomor 32 Tahun 2004 Tentang

Pendapatan Daerah

Penyelenggaraan Urusan

Pemerintahan.

2007. Permendagri Nomor

59 Tahun 2007 tentang Perubahan

Atas Permendagri No. 13 Tahun

2006 Pedoman Pengelolaan

Keuangan Daerah pasal 1 ayat 50

Akdon \& Riduwan. 2009. Rumus dan Data dalam Analisis Statistika. Alfabeta. Bandung.

Bati. 2009. Pengaruh Belanja Modal dan Pendapatan Asli Daerah (PAD) terhadap Pertumbuhan Ekonomi (Studi pada Kabupaten dan Kota di Sumatra utara) (http: www.google.com, diakses 20 september 2010)

BPS. 2010. Kabupaten Berau Dalam angka 2010. Badan Pusat Statistik. Kabupaten Berau.

Guritno, Mangkoesoebroto. 2004. Kebljakan Ekonomi Publik di Indonesia. PT Gramedia. Jakarta.

Harinaldi. 2005. Prinsip-Prinsip Statistik Untuk Teknik dan Sains. Erlangga. Jakarta.

Insukindro. 2004. Penerimaan Pajak. Djambatan. Bandung.

Jhingan, M. L. 2000. Ekonomi Pembangunan dan Perencanaan. D. Guritno [penerjemah]. Raja Grafindo Persada. Jakarta.

Lipsey, Richard G., dan Steiner, Peter O. 2001. Economics (Edisi Keenam). Harper International Edition. New York. 
Ekonomika-Bisnis Vol. 4 No.1 Bulan Januari Tahun 2013. Hal 25-44

Mankiw, N. G. 2006. Teori Makro Ekonomi Edisi Keenam. Imam Nurmawan [penerjemah]. Erlangga. Jakarta.

Mudrajad kuncoro. 2006. Ekonomika Pembangunan. STIM YKPN d/h Hamp YKPN. Yogyakarta.

Mardiasmo. 2002. Otonomi dan Manajemen Keuangan Daerah. Andi. Yogyakarta.

Nasucha, Chaizi. 2007. Peranan Informasi Pertanahan Dalam Pengelolaan PBB. Jurnal Survei dan Propeti Vol. 009 Oktober 2007.

Rahardja, Prathama dan Manurung, Mandala. 2008. Teori Ekonomi Makro Suatu Pengantar (Edisi Keempat). Lembaga Penerbit Fakultas Ekonomi Universitas Indonesia. Jakarta.

Rohmawati, Dewi Sintani. 2011. Analisis

Beberapa Faktor yang Mempengaruhi Belanja Daerah di Kabupaten Sumenep. Fakultas Ekonomi Universitas Pembangunan NASIONAL "Veteran" Jawa Timur. Saragih, J. P. 2003. Desentralisasi Fiskal dan Keuangan Daerah dalam Otonomi. Ghalia Indonesia. Jakarta.

Setiyawati, Anis. 2007. Analisis Pengaruh PAD, DAU, DAK dan Belanja Pembangunan Terhadap Pertumbuhan Ekonomi, Kemiskinan dan Pengangguran: dengan Pendekatan Analisis Jalur. Jurnal Akuntansi dan Keuangan Indonesia. Desember 2007, Vol. 4, No. 2, Hal. 211-228.
Sukirno, Sadono. 2004. Pengantar Teori Makro Ekonomi. PT Raja Grafido Persada. Jakarta.

Sugiyono. 2008. Statistik Untuk Penelitian. CV. Alfabeta. Bandung. Sunyoto, Danang. 2010. Uji Khi Kuadrat \& Regresi untuk Penelitian. Graha Ilmu. Yogyakarta.

Tarigan, Robinson. 2006. Ekonomi Regional teori dan aplikasi. Bumi Aksara. Jakarta.

Todaro, M. P dan Smith, S. C. 2006. Pembangunan Ekonomi Edisi Kesembilan. Haris Munandar [penerjemah]. Erlangga. Jakarta.

Todaro, Michael P. 2000. Pembangunan Ekonomi. Erlangga. Jakarta. 